\title{
Corruption and the European Criminal Policy
}

\author{
Msc Basri Shabani \\ PhD student, Military Academy "Spiro Moisiu" OPS Department, Tirana, Albania. \\ Email: basrishabani@yahoo.com
}

Doi:10.5901/ajis.2014.v3n3p252

\begin{abstract}
It is concluded that corruption is part of every society, whether it is developed or undeveloped, the question that arises is, what is the difference in these societies regarding level, while the fact of the existence of corruption as a phenomenon does not arise as a question at all. When we have this in mind, it is observed that the fight against this phenomenon must be permanent and without any compromise. Certainly, developed countries have better possibilities in fighting corruption in the sense of experience, methods and technologies that they possess, while developing and undeveloped countries remain to follow the best practices of these countries and greater political will of citizen to fight this phenomenon. It becomes even more complex when we consider that corruption as a phenomenon is very well connected with other crimes and especially it is not viewed separately from organized crime or money laundering, financial crimes or various forms of serious crime. Even more disturbing is the fact that corruption includes almost all spheres of society, including the private and public sectors, civil society. This creates bad opinion that somehow the whole society is corrupt. Forms used to express the corruption, are summarized as follows: provision, promise or giving of bribes to public officials; bribery of foreign officials; demand, accepting or receiving bribe by public officials; influence at work; aim to influence; Abuse of public property; misuse of office / position; bribery in the private sector; obstruction of justice. But this is not limited by all this, since the possibility remains to constantly "modernize" the forms of corruption. Efforts to define corruption as a phenomenon have been, and remain numerous, but we still do not have a single and accepted definition except the efforts to include as many more elements and forms of expression of this phenomenon. Thus, a comprehensive definition is given by the Civil Convention on Corruption, drafted by the Council of Europe. Under this Convention, "corruption" means requesting, offering, giving, receiving, directly or indirectly any bribe or other benefit, which will affect the proper conduct or behavior or the request towards certain behavior of the one who receives bribe, or whoever else benefits from it'.
\end{abstract}

\section{Introduction}

Corruption is considered to be society's cancer. Perhaps it is pathetic for such a conclusion, but since there is no country in which this criminal phenomenon does not exist, we dare to say this allegorically.

Along with other policy developments and especially the great media attention to this phenomenon, the state policies but also international ones always are being developed to prevent and stop this phenomenon. Despite taken actions and the development of criminal policies by many different countries, some countries have achieved to lower the level of criminality and make it smaller than in some other countries. But there is no pattern to stop or delete it from the criminal dictionary, because there are no states with zero corruption and an ideal model to fight it. In fact, the development of good policies is not enough to influence positively to this phenomenon. But firstly there is a need for political will to combat it and secondly policies should be applied on the spot without intervention and supported from all spheres of society. Certainly the development of the technology requires tools and prepared people in the sphere of combating this crime and especially in its prevention.

This draft attempts to give a brief overview of this phenomenon and in this context it will be assessed how far, in which important state institutions this phenomenon is extended, what are the elements that define corruption, and the corruption situation in the global sphere.

One part of this draft will attempt to present the European policies on corruption and crime, especially in areas which we are trying to reach and influence by these policies.

\section{Methods}

The study includes a deep and versatile survey regarding the corruption as a widespread phenomenon in all countries with special emphasis in countries policies in combating this phenomenon.

Working methods have been adapted to the requirements of this research: 
Descriptive methods - show some statistics of the level of corruption in various countries including the trust that citizens have in institutions.

The method of research - explore the possibilities and ways by which measures can be undertaken to combat this phenomenon.

The method of analysis - through which we analyze the benefits and shortcomings of efforts made to combat this phenomenon and the challenges that await us in the future.

The comparative approach - analyze the current situation in underdeveloped and developing countries and compare it with the European Union and beyond.

\section{The Purpose of the Study}

Corruption is present in every society and fighting it is permanent. The purpose of this draft is to give a little bit of contribution in continuous and comprehensive attempts of anyone in the prevention and minimization of this phenomenon. Fighting of this phenomenon is possible if we have strong anticorruption policies which in itself should contain the necessary legislation and sustainable and serious institutions based on goodwill of political parties and citizens in general, to cooperate in order to be given a comprehensive blow them to those who cause and develop this phenomenon.

\section{Literature Review}

Corruption is one of the most complex phenomena of society. The complexity of this phenomenon derived from the cause that by this, all spheres of social life are attacked. 'Corruption as such constitutes a major threat to democracy "(Vesel Latifi / Criminal Policy, p. 242). This is how professor Latifi defines the phenomenon of corruption which gives us to understand that corruption is destructive element of society, very complex from inside because of the "inclusiveness" that it carries inside. In addition to this, as a phenomenon it poses a risk and threat to democracy, in other words suffocates the development and progress of the state and society.

Many countries believe that corruption is one of the biggest problems with the states. "Corruption is considered a major social problem in Albania and Romania", then as the second problem is classified in Bosnia and Croatia, as a third problem in Macedonia, and as the fourth in a row in Bulgaria "Crime and Its Impact on the Balkans, p.88". Therefore corruption is spread out in all countries; the difference is its level. Undoubtedly highest level of corruption pattern is observable in underdeveloped countries and developing ones. Developed countries, however low is their level of corruption, are not totally exempt from this phenomenon.

Authors, various organizations and institutions are trying to give definitions of corruption. Though not a limited definition, most of them have summarized the elements and frequent forms by which the corruption is characterized. Definition of organization Transparency International, says that "Corruption involves behavior of public officials, no matter whether they are politicians or civil servants, which behavior they / them legally or not introduce themselves to others, in order to misuse of public power is given "Wikipedia / Political Corruption. Another definition which attempts to define political corruption says that "corruption is defined as the use of government power by its officials for illegal benefits" Corruption / A Glossary of International Standards in Criminal Law, p 23.

Now anti-corruption policies are not only the concern specific of countries, but include a global context. Besides drafting appropriate legislation, sustainable institutions, political and public will, a system of monitoring processes and implementation should exist.

It also requires assessment and monitoring of implementation and sanction of violations and requires transparency in particular of public financial management. Corruption and the European Neighborhood Policy (ENP), p.2. Transparency is important for citizens, their notification over the measures and the effects caused by the anti-corruption fight. This motivates them to collaborate even more and to contribute in this direction.

\section{Corruption as a Phenomenon and Its Extension}

Corruption is one of the most complex phenomena of society. The complexity of this phenomenon derives from the cause that by this, all spheres of social life are attacked. As such 'Corruption constitutes a major threat to democracy'lt is considered that corruption attacks the social, economic and political dimension and even beyond. Specifically corruption showed expansion in all institutions both public as well as private, notwithstanding here NGOs, economic state organization, liberal market, up to the different layers of the population. 
No society is immune against this criminal phenomenon, whether they are societies with developed democracy or societies in progress and undeveloped. When analyzing the effect of corruption, we can conclude that corruption has a negative effect exactly in developing countries and to those undeveloped, on economic aspect because it attacks the already limited budget that these countries have, and affects the distribution of inequitable use of public funds; in the private sphere causes great loss and increases the market cost which is expressed through higher prices which hits then the customers in social aspect because it strikes the broad range of poor and powerless people stricken people because if they want to get the necessary services, they should pay different amounts in illegal way or to offer various favors to certain people in order to come up to the performance of various tasks.Corruption as a phenomenon is very well connected with other crimes and especially not viewed separately from organized crime or money laundering, financial crimes or various forms of serious crime. Therefore in many articles, analyzes and drafts it is considered that corruption is an integral part, of; political parties, parliament / legislature, the private sector business, the media , the military, nongovernmental organizations, the religious organizations, educational system, legal, judiciary, police, civil registers, the maintenance activities, in taxes, etc.

Forms by which corruption is expressed in principle are summarized but not limited only to: provide, promise or giving of bribes to public national officials; bribery of foreign officials; demand, accepting or receiving bribe by public officials; influence at work; aim to influence and evidence; abuse and other forms of abuse of public property; misuse of office / position; bribery in the private sector; misuse of property in the private sector; use of property that resulted from corruption; obstruction of justice.

1 Vesel Latifi/Politika Kriminale, f. 242

Also corruption is classified as economic crime and as such includes other types of crimes or acts attributable to corruption as follows; money laundering; financial crimes; misuse of bids; misuse procurement procedures; misuse of accounts and audits; Counterfeit data etc.

\section{Definition of Corruption}

Regarding corruption, there are many definitions, different, whether definitions that determine what actually counts as corruption, or actions that can be attributed to corruption.

Organization for Economic Cooperation and Development (OECD, English), has provided some insights into the definition of corruption. As the organization which monitors the Convention on combating bribery of public/foreign officials in international commercial transactions, has given two definitions related to corruption, criminal or penal definition of corruption and political definition of corruption.

According to the criminal definition of corruption, it is considered that there is no line regarding what actually is corruption. But instead of defining, has counted a wide range of actions to contain the corrupt acts itself. Some of these actions to be mentioned are: bribery, influence act, misuse of public funds, unreasonable and unjustified behavior on public property and public officials, misuse of public property, and other behaviors that have different impacts. While the definition for political purposes is more known. From this aspect the most used definition which not only defines what is corruption, but also covers a broad spectrum of corruption actions. According to this definition, corruption presents 'abuse of public and private office for personal gain'. ${ }^{1}$

Another definition which attempts to define political corruption says that "corruption is defined as the use of government power by its officials for illegal benefits"

The same perception of the definition of corruption is also shared by the United Nations Office on Drugs and Crime, which writes that corruption in general involves the use of public power for personal gain, but also mentiones other actions as bribery, fraud procurement procedures, then misuse of public funds etc.

Definition of organization Transparency International, says that "Corruption involves behavior of public officials, no matter whether they are politicians or civil servants, with which behavior they / them legally or not introduce themselves to others, in order to misuse the given public power."

However, corruption cannot be viewed separately from organized crime and other crimes. Criminal Code of Kosovo, has incriminated taking and giving bribes. Even local authors talk about political corruption which has to do with taking political power functions or holding certain privileges.

While at the level of the European Community, in documents that deal with corruption by criminal aspect such as

\footnotetext{
2 Corruption/A Glossary of International Standards in Criminal Law, f 22

${ }^{3}$ Wikipedia/Political Corruption

${ }^{4}$ Corruption/Glossary of International Standards in Criminal Law,p.23
} 
the Criminal Law Convention on Corruption and other documents, has not set a definition but actions have been counted. But the Civil Convention on Corruption, drafted by the Council of Europe, for the purposes of this Convention, "corruption" means requesting, offering, giving, receiving, directly or indirectly any bribe or other benefit, which will affect the proper conduct or behavior or in the request against certain behavior of the recipient of bribes, or whoever else benefits from it '.

Most corrupted vital institutions: it is reported that the police is the institution that is mostly involved in corrupt activities, the second is the judiciary and registry services and and services for granting permits. But the order varies from country to country, from region to region. For example, while in Africa, Asia, Latin America and Eastern Europe, police is considered the most corrupted institution, in the states of the European Union (EU), medical services lead among corrupted institutions, while in North America, the judiciary is seen as the leader of this group

Perception of corruptions in different sectors and institutions: political parties are considered as most corrupted institutions, however there is a strong relationship between people's perception of corruption in key services and their experiences regarding bribes, when they come in touch with these services.

\section{European Criminal Policies on Corruption}

Corruption is the black hole of each state. The level of corruption shows, the stability of institutions and the degree of democracy in the provision of services to citizens, on whose mandate their institutions stay.

Not only for the fact that corruption is perceived as a part of organized crime and combating these crimes is very difficult especially if you try to do it only in the national level, but the difficulty of this combat is based on several reasons of which we mention the fact that in this criminal phenomenon are included people who have power and authority, and the level of reporting of this crime is relatively low in one hand and the ability to gather evidence is very small. This becomes especially difficult in cases where there is no political will to fight it,the lack of adequate legislation and especially the willingness of cooperation between states.

This is especially evident in developing countries and transitional countries where the biggest problems occur because of fragility in the functioning of democratic institutions.

\section{European Legislation}

European policies and o corruption and in particular the legislative ones are lying in some dimensions, in the criminal, civil, economic, but also through acts of key institutions of the EU.

European Security Strategy, for a more secure Europe in a Better World, one of the five main threats to security has listed the organized crime as one of the threats faced by Europe in this century and in this way has open debate on the creation of policies to combat this crime. Considering that in many cases corruption is part of organized crime or to consider that along with it we consider that watching from the broader point of view it is a good legal basis for declaring the war against this phenomenon. However, we consider that the main document for corruption is the Criminal Law Convention on Corruption, 1999, launched in Strasbourg and Additional Protocol to this Convention of 2003.

Then, the Civil Law Convention on Corruption, as of 1999, which also in Section 2, has defined corruption. This Convention is very important because with her signature states have accepted providing judicial measures that may be required for compensation of damage to persons who have suffered damage from corruption.

Criminal Law Convention on Corruption was announced by the Council of Europe. It has reiterated the readiness of the countries cooperation in the fight against corruption. Council also through this convention has attempted to contribute to the punishment of corruption and harmonization of the of economic crime laws.

By the end of 2007, this Convention had been signed by 35 states.

This Convention does not determine the definition of corruption. But it has counted a broad spectrum of actions which constitute corruption behavior and especially the actions of public officials, but also including the private sector.

Convention on combating foreign officials receiving bribery, adopted by the Organization for Economic Cooperation and Development (OECD), which entered into force in 1999 that represents most of the countries that are involved in this trade. It addresses only the acceptance of bribes by foreign officials in international transactions related to business. Also this convention has built Bribery Working Group to monitor implementation of the Convention in signatory states.

Then the Council in order to reinforce cooperation between member states in the fight against corruption and the involvement of the officials from European Member States has issued an act in 1997, the Convention against Corruption, which is based on the Treaty of the European Union. Through this convention it was meant to design the fight against European officials, or national officials of member states of the EU.Also here explicitly is stated that this 
document requires Member States to ensure that the fight against corruption, including active and passive forms of corruption among national officials. In this way it offers the territorial extension of the convention, the entities involved in criminal violations.

There are also a number of documents such as the Convention on Money Laundering, Control, Seizure, Proceedings and Financing Terrorism, and the Convention for the Prevention of Terrorism. Both these conventions contain provisions that may apply in cases of corruption.

\section{Punitive Policies}

Are a form of war against the crime and have a repressive but also preventive dimension.

Conventions governing the criminal phenomenon of corruption require that corrupt acts are punished effectively, proportionately and to punish even criminally when physical persons get involved as well as the possibility to be considered a limitation of freedom of movement and extradition.

Also it is required that the weight of the punishment should be in harmony with the severity of the offense. The UN Convention also seeks to create opportunities for the devaluation of the order of the court in cases involving irregularities when official persons are involved.

Generally it is required that punishment is proportionate to the gravity of the offense but not in great disproportion to the severity of the offense. Also it is required to settle administrative and civil penalties.

We can generally say that the sanctions required are; criminal, civil and administrative.

Some of the sanctions that we find in these legal documents are also;

Confiscation

- Confiscation of the bribe amount received, the goods obtained by taking bribes and tools

- to commit a crime,

- Fines and confiscation of equivalent value,

- Confiscation of converted items a and goods benefited from them,

- Confiscation from the third person.

\section{Constructed Standards and Anti-Corruption Policies}

Based on the existing legislation at the level of European countries, we may conclude that European policies related to corruption are some dimensional, including drafting legislation, supporting and other guiding acts issued by the Council of Europe or the pillar of the Community or the European Commission.

Some of the tools of war against corruption have been also created at the level of plans and strategies for collaboration as for example the European Neighborhood Policy in 2004, which actually represents a political commitment against corruption, and requires cooperation between states as a tool for war against corruption.

In fact, this re-emphasizes that the political precondition against corruption is a very powerful tool in order to; strengthen democracy, the rule of law, judicial reform and the fight against organized crime and corruption; respect for human rights and fundamental freedoms, freedom of thought; support of civil society; cooperation with the International Tribunal; commitments in European policies against terrorism, weapons of mass destruction and commitment to conflict resolution. It also requires assessment and monitoring of implementation and sanction of violations and requires transparency especially in public finance management.

Or another tool is Istanbul Action Plan in which are included the action plan for Armenia, Azerbaijan, Georgia, Kazakhstan, Kyrgyzstan, Russian Federation, Tajikistan and Ukraine in 2003 and which plan was later also revised and considered to be a document with legal effect and based on which the recommendations are then given to these countries in developing national policies against corruption.

We can conclude that European criminal corruption policies are addressed in several ways, in order to design effective policies on anti-corruption fight.

Act which legalizes communication between the Commission, the EU Council and Parliament, by considering that "corruption is the abuse of power for private gain '. By this act there are some stemming principles that should be considered as elements of anti-corruption policy in Europe in the future.

\section{These principles are summarized into:}

- A strong political commitment to fight corruption;

- Implementation of the current anti-corruption instruments;

$-$ 
Member States of the EU should develop and improve investigative tools and collect more staff to fight corruption;

Member States and other EU bodies that need to redouble their efforts to combat corruption;

- To develop common standards of integrity and include them in public administration in the EU;

- Private sector efforts to raise integrity and shared responsibility

- The fight against political corruption, and uncertain financing of the institutions should not stop;

- Issues of corruption must be addressed and debated with candidate countries and third countries; The EU should continue to make the fight against corruption an integral part of foreign policy market.

- In this way, this communication has given effect even to legal instruments, through the cooperation of police and judicial fields;

- Eurojust (in the field of judicial cooperation) - with a mandate to fight fraud and corruption, money laundering and participation in a criminal organization;

Europol - the European Office of the policy is extended;

The Commission has given a proposal to appoint a European Prosecutor for finances, to deal with corruption which affects the interests of the community.

\section{European Arrest Warrant}

\subsection{Directive on money laundering}

And a range of other acts are still under construction.

Council of the European Union in 2005 has issued a draft resolution regarding corruption, by means of which it calls the Commission, the Council and the European Parliament to draw up a EU-based comprehensive anti-corruption policy based on; achieving further progress in the fight for the prevention and suppression of corruption at the level of the EU.

Defining those areas where improvement is needed;

- Suggest future initiatives of the EU, the EU institutions, member states and countries outside the EU.

\section{Policies for Candidate Countries}

States which join the EU would have had to meet certain standards and these standards have been different from the first expansion.

The Copenhagen criteria is the most known standard needed/requested from states to fulfill as well as the criteria for economy, political and human rights. Then each of these areas requires a series of actions to be taken by the state to strengthen all these areas and to be in accordance with those of other member states.

Referring particularly to the scope of corruption at the level of Europe, anti-corruption policy of the EU has introduced ten (10) principles for the candidate countries to the EU.

These 10 principles are known as 'general principles' and belong to the public sector and the private sector;

- The need for strong political support for addressing corruption,

- Becoming part of the relevant international instruments,

- Implement legislation effectively

- Preservation in relation to the recruitment policies of private and public civil servants

- Integrity, accountability and transparency in all sectors of public administration,

- Development of codes of conduct for all public administration sectors,

- Protection for the public and private sector customers

- Encourage the public to recognize the effect of corruption

- Ensuring that the special troops have not influence on the policy-making process

- Support of the private sector in recognizing and combating corruption.

\section{Conclusion}

We can conclude that corruption as a criminal phenomenon has an effect on social progress, economic progress, democracy building, the rule of law and human rights and attacks the stability of a country's institutions. Although there is no consensus for the definition, there is a consensus regarding the risk that it presents in support and assistance for other 
dangerous crimes. Values of corruption appear to be alarming, and show clearly that there is no country that is immune to this phenomenon. This has necessitated the construction of anti-corruption policies, including legislation, punitive policies, standards and support policies, by creating also monitoring bodies. It has been worked at the European level in making policies to fight corruption not only at the national level but even beyond up to the wider global level. These policies have been extended in several dimensions, especially focusing on the legislation. Perhaps in the near future we will find means and ways to remove those people who have the chance to be involved in acts of corruption by direct contact with the phenomenon as a whole or with operations in particular, as for example bound system of bank payments that does not give the opportunity to manipulate with dirty money in the countries which have developed this system. Also in the European level the debate has been raised about 'Doctrine of Humanities, especially in security matters including criminal matters as the main component of security, but human doctrines should have been another topic to elaborate in the future.

\section{References}

Commission of the European Communities / Kosovo (Under UNSCR 1244/ 99) 2008 Progress Report /Brussels , 2008

Council of Europe / Civil Law Convention on Corruption / Strasbourg 1999

Council of Europe /Additional Protocol to the Criminal Law and Convention on Corruption

Council of Europe /Criminal Law Convention on Corruption / Strasbourg 1999

Council of the European Union/ Draft Council Resolution concerning a Comprehensive EU Policy Agains Corruption/ Brussels, 2005.

European Commission / Lucinda Mac Mahon/EU Anti- Corruption Policy and 10 Principle for Candidate Country

European Security Strategy / A Secure Europe in a Better World/ Brusels , 2003.

Francis Fukuyama/Ndertimi i Shtetit/Tirane,2008

Halili, Dr. Ragip /Kriminologjia/ Universiteti i Prishtinës / Prishtine , 2005

Latifi, Dr. Vesel / Politika Kriminale /Universiteti i Prishtinës/ Prishtine, 2008.

OECD/ Corruption -A glossary of International Standards in Criminal Law / OECD, 2008

U4 Anticorruption Resource Centre/ Corruption and the European Neighborhood Policy ( ENP) , 2008

United Nation Office on Drugs and Crime/ Crime and its Impact on the Balkans, 2008

Transparency International / Report on the Transparency International Global Corruption Baromater 2007/ Berlin , Gjermani, 2007

EU Web pages/ treates, internet resource ;

Comprehensive EU anti-corrupsion policy

Convention against corruption involving officials

United Nation Convention agains Corruption 